\title{
Recent geodetic mass balance of Monte Tronador glaciers, northern Patagonian Andes
}

\author{
Lucas Ruiz ${ }^{1}$, Etienne Berthier ${ }^{2}$, Maximiliano Viale ${ }^{1}$, Pierre Pitte ${ }^{1}$, and Mariano H. Masiokas ${ }^{1}$ \\ ${ }^{1}$ Instituto Argentino de Nivología, Glaciología y Ciencias Ambientales (IANIGLA), Gobierno de Mendoza, Universidad \\ Nacional de Cuyo, CONICET, Mendoza, 5500, Mendoza, Argentina \\ ${ }^{2}$ Laboratoire d'Etudes en Géophysique et Océanographie Spatiales, Centre National de la Recherche Scientifique (LEGOS - \\ CNRS, UMR5566), Université de Toulouse, 31400 Toulouse, France \\ Correspondence to: Lucas Ruiz (lruiz@mendoza-conicet.gob.ar)
}

Received: 4 July 2016 - Discussion started: 31 August 2016

Revised: 5 December 2016 - Accepted: 31 January 2017 - Published: 24 February 2017

\begin{abstract}
Glaciers in the northern Patagonian Andes (35$46^{\circ} \mathrm{S}$ ) have shown a dramatic decline in area in the last decades. However, little is known about glacier mass balance changes in this region. This study presents a geodetic mass balance estimate of Monte Tronador $\left(41.15^{\circ} \mathrm{S} ; 71.88^{\circ} \mathrm{W}\right)$ glaciers by comparing a Pléiades digital elevation model (DEM) acquired in 2012 with the Shuttle Radar Topography Mission (SRTM) X-band DEM acquired in 2000. We find a slightly negative Monte-Tronador-wide mass budget of $-0.17 \mathrm{~m}$ w.e. $\mathrm{a}^{-1}$ (ranging from -0.54 to $0.14 \mathrm{~m}$ w.e. $\mathrm{a}^{-1}$ for individual glaciers) and a slightly negative trend in glacier extent $\left(-0.16 \% \mathrm{a}^{-1}\right)$ over the $2000-2012$ period. With a few exceptions, debris-covered valley glaciers that descend below a bedrock cliff are losing mass at higher rates, while mountain glaciers with termini located above this cliff are closer to mass equilibrium. Climate variations over the last decades show a notable increase in warm season temperatures in the late 1970s but limited warming afterwards. These warmer conditions combined with an overall drying trend may explain the moderate ice mass loss observed at Monte Tronador. The almost balanced mass budget of mountain glaciers suggests that they are probably approaching a dynamic equilibrium with current (post-1977) climate, whereas the valley glaciers tongues will continue to retreat. The slightly negative overall mass budget of Monte Tronador glaciers contrasts with the highly negative mass balance estimates observed in the Patagonian ice fields further south.
\end{abstract}

\section{Introduction}

Glacier mass balance is crucial to understand the response of glaciers to climate change and the implications of glacier changes to water resources and sea level rise (Intergovernmental Panel on Climate Change, 2013). Mass balance is commonly obtained by the glaciological method of stakes and pits or with the geodetic method, in which two elevation surveys of the surface of the glacier are subtracted to calculate the volume change (Cogley et al., 2011). In recent years, the geodetic mass balance has become a widely used technique to assess elevation and volume changes of glaciers over a period that usually spans from a few years to decades (Wang and Kääb, 2015). Although this technique does not resolve the seasonal mass balance, it has become widely used to measure the contribution of glaciers to sea level rise and to reanalyse and correct long-term glaciological mass balance series (Berthier et al., 2007; Huss et al., 2009; Kääb et al., 2012; Willis et al., 2012a, b; Zemp et al., 2013).

Due to difficulties sustaining long-term research programmes, up-to-date glaciological mass balance series with more than 10 years of observations are available for only three small glaciers in the Southern Andes (Fig. 1); Guanaco $\left(29.348^{\circ} \mathrm{S} ; 70.015^{\circ} \mathrm{W} ; 1.637 \mathrm{~km}^{2}\right)$; Echaurren Norte $\left(33.83^{\circ} \mathrm{S} ; 69.91^{\circ} \mathrm{W} ; 0.4 \mathrm{~km}^{2}\right)$ and Martial Este $\left(54.78^{\circ} \mathrm{S}\right.$; $68.4^{\circ} \mathrm{W} ; 0.09 \mathrm{~km}^{2}$ ). Mass balance data for the northern Patagonian Andes have only been reported for 2002 2003 and 2003-2004 for the Mocho-Choshuenco glacier $\left(39.91^{\circ} \mathrm{S} ; 72.03^{\circ} \mathrm{W} ; 4.8 \mathrm{~km}^{2}\right.$; Fig. 1). Unfortunately, the lack of mass balance data hampers the possibility of exploiting the 


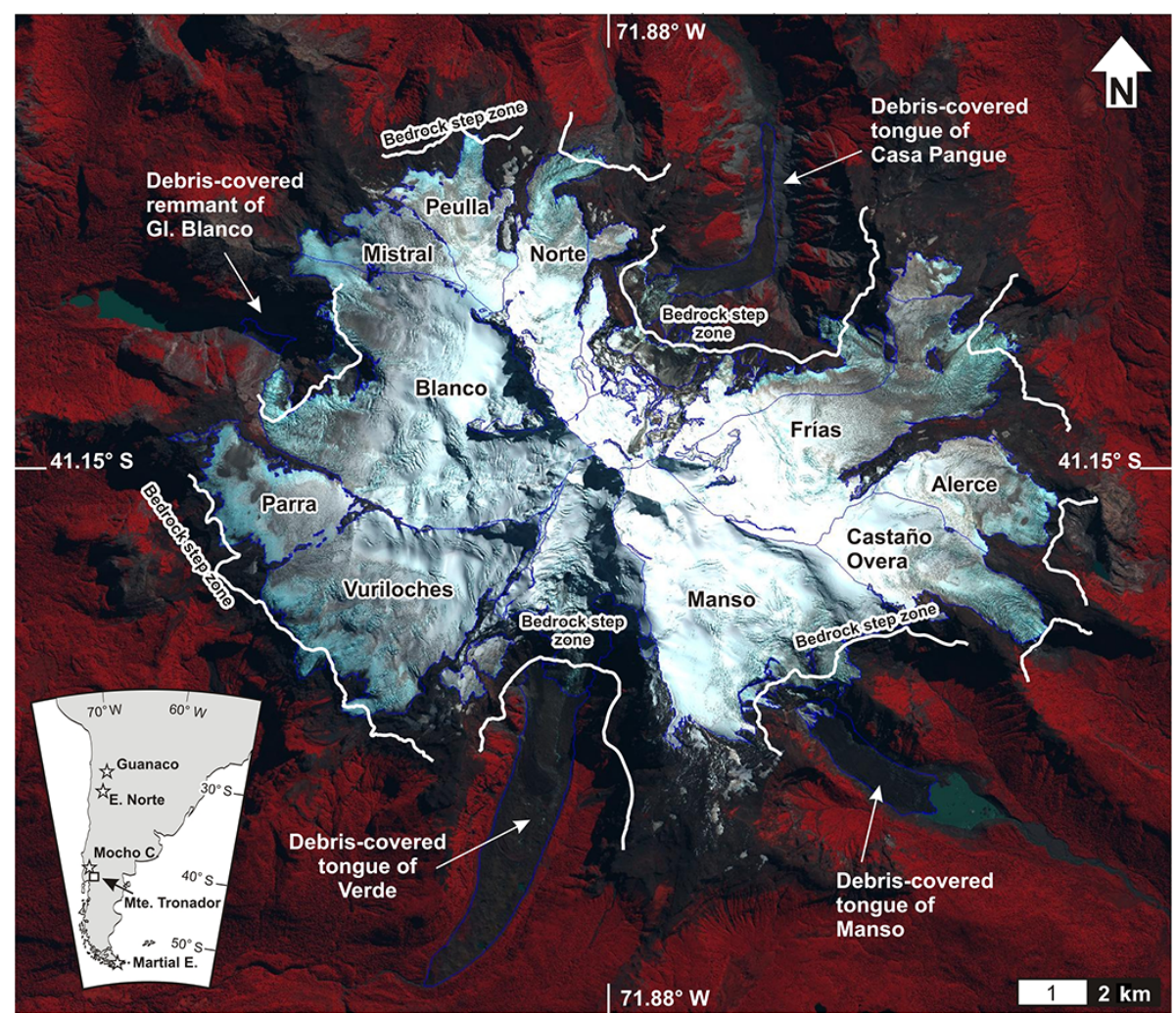

Figure 1. False-colour pan-sharpened Pléiades image of Monte Tronador from 7 March 2012 (RGB bands 3, 2 and 4, ${ }^{\circ}$ CNES 2012 , Distribution Airbus D\&S). Individual glacier limits are indicated by the thin blue line. The thick white line shows the location of the bedrock cliff discussed in the text. The inset shows the location of Monte Tronador and other glaciers with long mass balance measurement series in the Southern Andes (22-55 S).

relatively more complete and longer glacier fluctuation series available for this region (Davies and Glasser, 2012; Leclercq et al., 2012; Masiokas et al., 2009; Paul and Mölg, 2014; Ruiz et al., 2012).

In this study, we provide recent thickness changes and estimate glacier-wide mass changes over the Monte Tronador glaciers. This was achieved by combining two elevation data sets, a Pléiades digital elevation model (DEM) of 21 April of 2012, and the German Aerospace Center (DLR) Shuttle Radar Topography Mission (SRTM) X-band synthetic aperture radar DEM (http://eoweb.dlr.de) of February 2000. Due to its shorter wavelength and smaller penetration, the SRTM $\mathrm{X}$-band is more suitable for estimating elevation changes in snow or ice surfaces (Surdyk, 2002a). However, it has not been as widely used for glacier elevation change studies as the SRTM C-band (Neckel et al., 2013; Rankl and Braun, 2016) because of its discontinuous spatial coverage. This is not an issue in Monte Tronador where there is a full SRTM $\mathrm{X}$-band coverage. We also analysed the trends and variability of temperature and precipitation over the last 85 years using nearby surface station data to investigate possible influences of climate on the observed glacier mass changes.

\section{Study area and climatic setting}

Monte Tronador $\left(41.15^{\circ} \mathrm{S} ; 71.88^{\circ} \mathrm{W}\right.$ ) is a $3475 \mathrm{~m}$ a.s.l. (metres above sea level) extinct stratovolcano located in the northern Patagonian Andes along the Argentina-Chile border (Fig. 1). The climate on the northern Patagonian Andes is largely modulated by the weather disturbances embedded in the midlatitude westerlies (Hoskins and Hodges, 2005). Weather disturbances and prevailing winds coming from the Pacific Ocean are more frequent and stronger in winter. However, associated frontal precipitation systems move over the Patagonian Andes all year round (Garreaud, 2009). Since the Patagonian Andes are oriented in a north-south direction, perpendicular to prevailing winds (westerlies), there is a marked precipitation gradient in the across-barrier direction. Annual precipitations around the latitude of the Monte Tronador increase from $1000-1500 \mathrm{~mm}$ on the Pacific coast to more than $3000 \mathrm{~mm}$ on the western slopes in Chile (Viale and Garreaud, 2015), and then sharply decrease to less than $1000 \mathrm{~mm}$ on the eastern slopes in Argentina (Lenaerts et al., 2014; Smith and Evans, 2007).

The upper slopes of Monte Tronador host one of the largest contiguous ice covers in the northern Patagonian Andes ( $\sim 57 \mathrm{~km}^{2}$ in 2012; Ruiz et al., 2015). Based on their 
morphological characteristics, Monte Tronador glaciers can be grouped into valley glaciers (Verde, Casa Pangue, Manso and Blanco) and mountain glaciers (Alerce, Castaño Overa, Frías, Norte, Peulla, Mistral, Parra and Vuriloches). Based on our most recent results, we introduced some modifications to the glaciers outlines presented by Ruiz et al. (2015). We renamed glaciers No Name 2 and No Name 3 "Mistral" and "Peulla", and the split glacier No Name 1 (Ruiz et al., 2015) "Parra" and "Vuriloches".

Valley glaciers $\left(6\right.$ to $\left.11 \mathrm{~km}^{2}\right)$ descend below a massive bedrock cliff or high slope zone (Fig. 1) present all around Monte Tronador around 1700 to $1400 \mathrm{~m}$ a.s.l., whereas debris-covered tongues or ice remnants are located at elevations between 1400 and $600 \mathrm{~m}$ a.s.l. Mountain glaciers ( 1 to $5 \mathrm{~km}^{2}$ ) are debris free and do not descend below the bedrock step.

As outlined in Ruiz et al. (2015), Monte Tronador glaciers follow a radial flow pattern, with maximum surface speeds of $400 \mathrm{~m} \mathrm{a}^{-1}$ associated with steep icefalls. The debris-covered tongue of Casa Pangue and the snout of Verde glacier (Fig. 1) are almost stagnant, whereas Ventisquero Negro shows acceleration in its front due to calving into a proglacial lake. Frías glacier also shows acceleration in its front due to dry calving, while the rest of the glaciers have their maximum surface speed close to the equilibrium altitude line (ELA) (1900-2100 m a.s.1.).

All glaciers in this area were substantially larger during the Little Ice Age between ca. AD 1650 and 1850 (Villalba et al., 1990; Masiokas et al., 2009, 2010). Presently, however, most of these glaciers show a clear retreating (Paul and Mölg, 2014) and thinning pattern (Masiokas et al., 2009), except for Verde, which remains in contact with Little Ice Age moraines. Bown and Rivera (2007) and Masiokas et al. (2008) indicated that a regional warming trend, together with a concurrent decrease in precipitation, could partly explain the recent regional retreat observed in the northern Patagonian glaciers. Leclercq et al. (2012) found that the overall retreat of Frías glacier between 1639 and 2009 could be best explained by an annual mean temperature increase of $1.2{ }^{\circ} \mathrm{C}$ or a decrease in annual precipitation of $34 \%$, most of which would have occurred during the 20th century.

\section{Data and methods}

\subsection{Shuttle Radar Topography Mission X-band synthetic aperture radar DEM}

The Shuttle Radar Topography Mission (SRTM)-acquired data from 11 to 22 February 2000 with two interferometric synthetic aperture radar sensors: the American SIR-C sensor and the German-Italian X-SAR sensor. The SIR-C $(\lambda=5.6 \mathrm{~cm})$ covers a $225 \mathrm{~km}$ swath width and provides an almost complete DEM of the earth's surface between latitudes $60^{\circ} \mathrm{N}$ and $56^{\circ} \mathrm{S}$ (Farr et al., 2007). The X-SAR sensor $(\lambda=2.8 \mathrm{~cm})$ has a narrower ground track (swath width of $50 \mathrm{~km}$ ), and covers approximately half of the area sampled by SIR-C. The two data sets were processed independently. The SRTM C-band DEM was released by NASA Jet Propulsion Laboratory (JPL) in 2003 with an initial spatial resolution of 3 arcsec (Rodriguez et al., 2006). The DLR X-SAR SRTM DEM (hereafter SRTM-X) with a spatial resolution of 1 arc-second was produced by the DLR and has been freely available for scientific purposes since 2010 (Hoffmann and Walter, 2006).

Penetration of the radar signal into snow and ice is related to the physical parameters of snow and ice (water content, ice compactness, grain size and debris content) and system parameters such as radar frequency (Dall et al., 2001; Rignot et al., 2001). Due to its shorter wavelength, the $\mathrm{X}$-band must have a lower penetration in snow and ice than the C-band (Surdyk, 2002b). Stuefer et al. (2007) found a small elevation difference between SRTM band-C and GPS measurements on Perito Moreno glacier and Jaber et al. (2013) found that firn in the accumulation area of the southern Patagonian ice field was wet during the acquisition of SRTM, which inhibits the penetration of the radar signal. Since Monte Tronador is located further north it is reasonable to assume that the firn in the accumulation area was also wet due to surface melting, inhibiting the penetration of the X-band.

\subsection{Pléiades DEM}

The Pléiades DEM (hereafter PLEI) was generated from a triplet (back, nadir and front) of Pléiades images acquired on 21 April 2012 with the software PCI Geomatica v2013 (Berthier et al., 2014). An output DEM was generated from the pixel values with higher correlation scores between the three DEMs derived from the different combinations of images (nadir-back, nadir-front, and back-front). A post-processing scheme was applied to eliminate anomalous values (Ruiz and Bodin, 2015). The final DEM has a spatial resolution of $2 \mathrm{~m}$ and accuracies of 0.5 and $1.06 \mathrm{~m}$ (RMSE) in horizontal and vertical directions. Accuracy was estimated using more than 2000 GPS elevation data collected on bare ground with a Trimble DGPS receiver on dynamic mode.

\subsection{Glacier outlines}

To measure the recent area changes of Monte Tronador glaciers, their outlines were manually digitized from a Landsat image of February 2000 and from a panchromatic Pléiades ortho-image derived from the nadir image of 21 April 2012 (Table 1). Surface displacement vectors of Ruiz et al. (2015) were used to identify the ice divides in the accumulation areas of the different glaciers.

\subsection{Adjustment and correction of DEM bias}

As SRTM-X and PLEI were generated using different approaches, they have a different spatial resolutions (30 and 
Table 1. Imagery and DEMs used in this study.

\begin{tabular}{|c|c|c|c|c|c|c|}
\hline \multirow{2}{*}{$\begin{array}{l}\text { Source of } \\
\text { information }\end{array}$} & \multirow[t]{2}{*}{ ID } & \multirow[t]{2}{*}{ Date } & \multirow{2}{*}{$\begin{array}{l}\text { Spatial res- } \\
\text { olution }[\mathrm{m}]\end{array}$} & \multicolumn{3}{|c|}{ Accuracy (m) } \\
\hline & & & & $X$ & $Y$ & $Z$ \\
\hline $\begin{array}{l}\text { Pléiades ortho } \\
\text {-image }\end{array}$ & $\begin{array}{l}\text { DS_PHR1A_ } \\
\text { 201204211445393_SE1_PX_ } \\
\text { W072S42_0220_01654 }\end{array}$ & $21 / 04 / 2012$ & 1 & 0.22 & 0.43 & $\mathrm{Nn}$ \\
\hline PLEI & Pléiades DEM & $21 / 04 / 2012$ & 2 & 0.33 & 0.21 & 1.20 \\
\hline Landsat image & LE72320892001038AGS00 & $07 / 02 / 2000$ & 30 & 10 & 10 & $\mathrm{Nn}$ \\
\hline SRTM-X & X-SAR SRTM DEM & $11-22 / 02 / 2000$ & 30 & 16 & 16 & 16 \\
\hline
\end{tabular}

Table 2. Shifts used to co-register the PLEI DEM with the SRTM-X DEM.

\begin{tabular}{rrrr}
\hline & $\begin{array}{r}\text { Shift in E/W } \\
(\mathrm{m})\end{array}$ & $\begin{array}{r}\text { Shift in N/S } \\
(\mathrm{m})\end{array}$ & $\begin{array}{r}\text { Shift in } Z \\
(\mathrm{~m})\end{array}$ \\
\hline PLEI-SRTM-X & 0.06 & -8.14 & 1.33 \\
\hline
\end{tabular}

$2 \mathrm{~m}$ ) and do not cover an integer time span (i.e. years). Consequently, it was necessary to apply different adjustments (coregistration, curvature and seasonality corrections) before extracting accurate glacier elevation changes (e.g. Gardelle et al., 2013). Due to the low penetration of X-band in snow/ice wet surface (Jaber et al., 2013; Rignot et al., 2001; Stuefer et al., 2007), we discarded any significant bias associated with it.

We determined the horizontal and vertical shifts of the DEMs using the universal co-registration method of Nuth and Kääb (2011). This approach corrects potential horizontal shifts $(X$ and $Y$ ) and vertical $(Z)$ biases based on the relationship of the elevation differences with terrain slope and aspect over off-glacier terrain (Fig. 2a and b). Before coregistration, PLEI was resampled to a $30 \mathrm{~m}$ grid cell (bi-cubic convolution) and all elevation changes outside the glaciers exceeding $\pm 100 \mathrm{~m}$ were discarded. Finally, the calculated shifts were applied to PLEI (Table 2).

The difference in DEM spatial resolution can lead to biases related to altitude in mountainous areas (Gardelle et al., 2012; Paul, 2008). In sharp peaks or ridges (where the curvature of the terrain is high) the coarse DEM tends to underestimate the altitude, whereas in deep troughs (where the curvature of terrain is highly negative) the coarse DEM tends to overestimate the height. This is due to its lack of capacity to reproduce high-frequency slope variations. The curvature bias, mentioned as "apparent elevation bias" by Gardelle et al. (2013), was corrected using the relation between height differences and maximum curvature estimated on stable areas off glaciers and without forest canopy (manually digitalized from the Pléiades images). A four-degree polynomial fit was used to make the correction but only within an acceptable range of curvature. For extreme curvature values, the relationship between elevation difference and curvature is noisy; thus these extreme values were discarded (Fig. 2c).

The time span between mid-February (acquisition time of SRTM-X) and mid-April (acquisition time of PLEI) represents a significant proportion of the ablation season. Thus, to estimate glacier mass balance over an integer number of years, it was also necessary to take into account the mass balance change of this period. To determine this seasonality correction, we used preliminary seasonal mass balance data for Alerce glacier available since 2013. At this site, summer measurements are made at intervals that range between 15 and 35 days, so we could estimate the mass loss rate during the ablation season. The preliminary data shows that between mid-February and the end of April in 2013, 2014 and 2015, mass balance glacier-wide loss for Alerce glacier was around $1 \mathrm{mw}$.e. each year. This is a significant loss of mass if we take into account that the annual glacier-wide mass balance values of this glacier were 0.4 and $-0.4 \mathrm{~m}$ w.e. for the years 2013/2014 and 2014/2015. As we do not have additional data to extrapolate the seasonality correction to the rest of the Monte Tronador glaciers, we applied the same seasonality correction $\left(1 \mathrm{~m}\right.$ w.e. $\left.\mathrm{a}^{-1}\right)$ to all glaciers.

\subsection{Mean elevation changes and mass balance calculation}

Before calculating the height and mass balance changes, we excluded all the void pixels in SRTM-X and PLEI, as well as those with extreme curvature values (Fig. 2c). The excluded cells represent $\sim 25 \%$ of the area covered by glaciers in 2000 . Here we briefly summarize the procedure to obtain the volume and glacier-wide mass balance (see Appendix A for a detailed description of the calculations).

To calculate the volume change for each glacier, elevation changes were analysed for $50 \mathrm{~m}$ altitude bands. Within each altitude band, we averaged the elevation change $\left(\mathrm{d} h_{n}\right)$ after excluding pixels for which absolute height differences differed by more than 3 standard deviations from the mean 

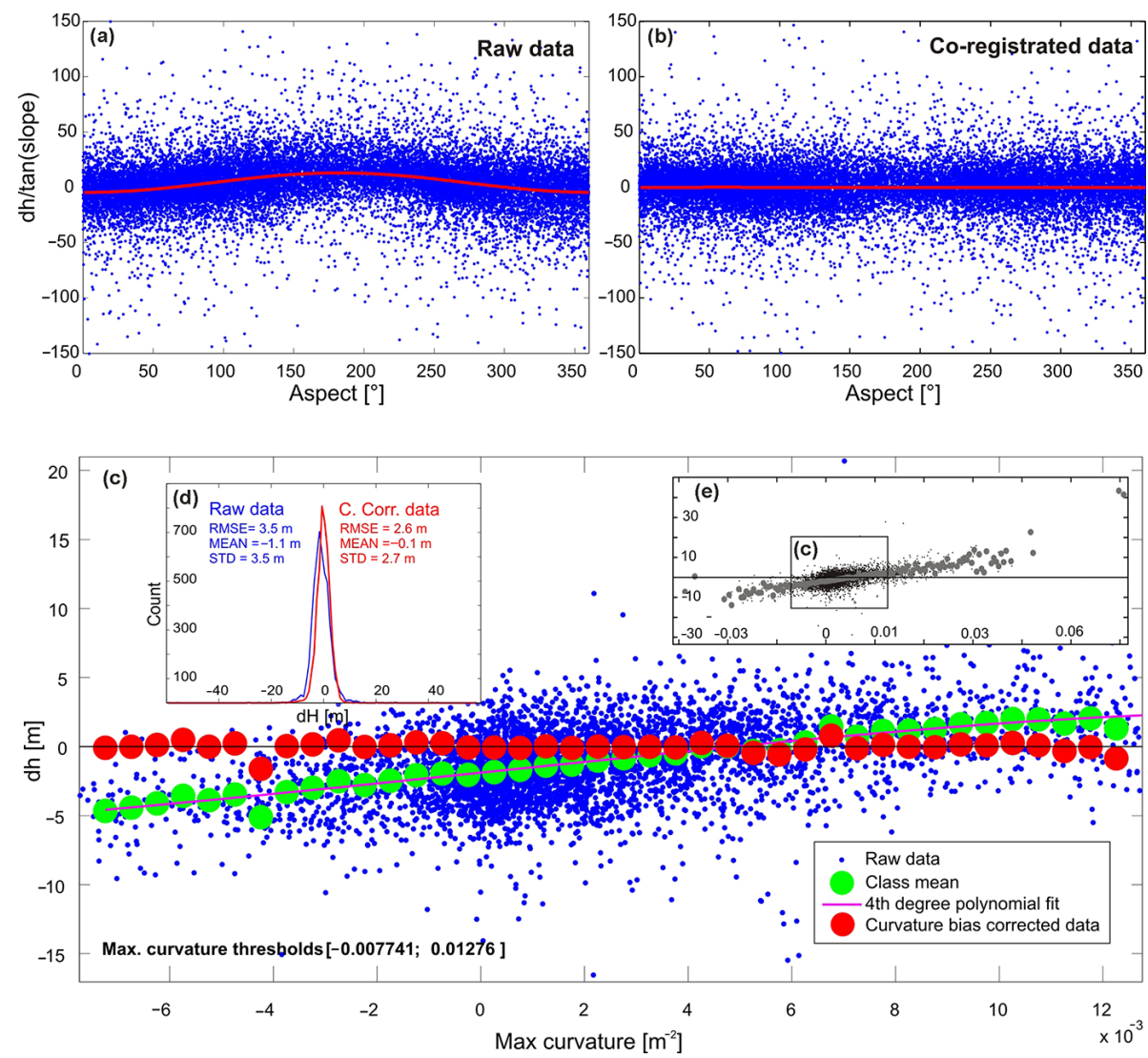

Figure 2. 3-D corregistration and curvature correction of the DEMs. (a) Elevation changes normalized by the tangent of the slope as a function of aspect for off-glacier cells. (b) Same data as (a) after applying the shifts. (c) Curvature correction. Green and red dots show the elevation difference averaged in curvature bins before and after the correction is applied. (d) Histograms of the height differences off-glacier and off-forest, before (blue) and after (red) the curvature bias correction. The RMSE, mean bias (MEAN) and standard deviation (STD) for each data set are shown. (e) Same as (c) but with all elevation data available. Note that most of the data are between the thresholds where the curvature bias correction works.

(Berthier et al., 2004) (Fig. 3). This is an efficient way to exclude outliers (less than $10 \%$ of the remaining data after eliminating the voids and the extreme curvature values), based on the assumption that elevation changes should be similar at a given altitude of the glacier. For those altitude bands for which there were no data (errors in the DEMs or values outside of an acceptable curvature range), an interpolation scheme was used to derive the elevation change at that particular elevation bin. If the bins with no data were located close to the maximum height of the glaciers (i.e. Vuriloches and Norte; Fig. $3 \mathrm{f}$ and $\mathrm{h}$ ) a nearest-neighbour interpolation method was used to maintain the same pattern of elevation change with elevation observed in the rest of the glacier. For those bins with no data located in the middle or in the snout of the glaciers (Castaño Overa, Manso and Blanco; Fig. 3e, $\mathrm{j}$ and $\mathrm{h}$ ) a linear interpolation method was used. Close to the edge of the rock cliff (snout of Castaño Overa; Fig. 3e), we found anomalous values showing an elevation gain in the 2000-2012 period. This artefact is due to the difference in the spatial resolution of the DEMs; the higher spatial resolution
PLEI (although it was resampled to $30 \mathrm{~m}$ ) resolves the edge of the cliff more sharply than the SRTM-X, which shows a gentler slope at the brink of the cliff producing the spurious gain of mass. This area around the lower reaches of Castaño Overa is quite small ( $0.8 \%$ of the total glacier area) and even if we neglect all the anomalous positive values, the change in the glacier-wide mass balance remains within the error bars.

The conversion of elevation change to mass balance requires knowledge of the density of the material that has been lost or gained and its evolution during the study period. Given the lack of measurements of density profiles over the entire snow/firn/ice column in Monte Tronador glaciers, we applied a constant density conversion factor of $850 \pm 60 \mathrm{~kg} \mathrm{~m}^{-3}$ (Huss, 2013).

\subsubsection{Elevation change error assessment}

The elevation change error estimate was calculated from the pixels of elevation change that were not covered by forest or ice in 2000 and 2012. The error $\left(E \Delta h_{i}\right)$ for each pixel 

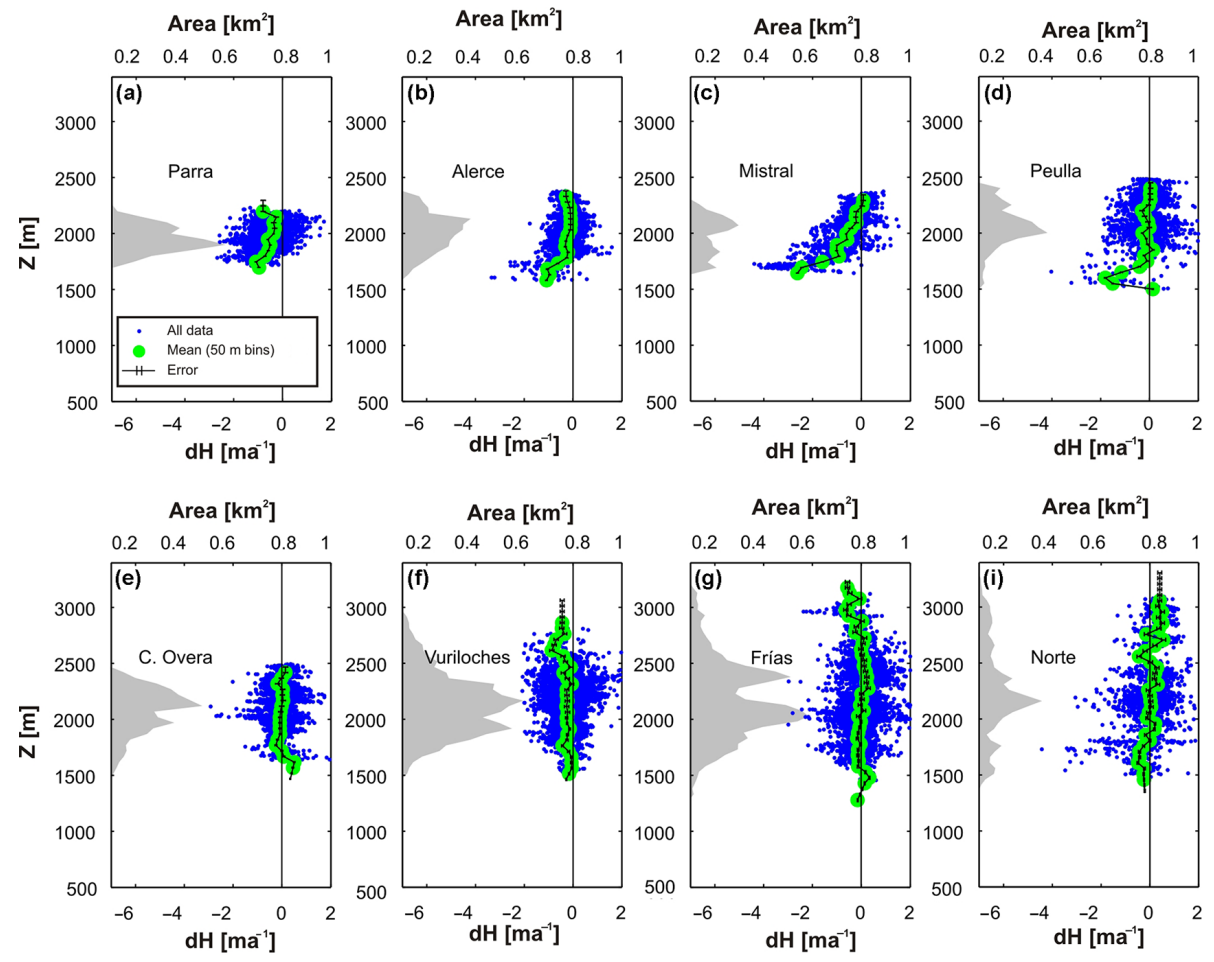

Area $\left[\mathrm{km}^{2}\right]$
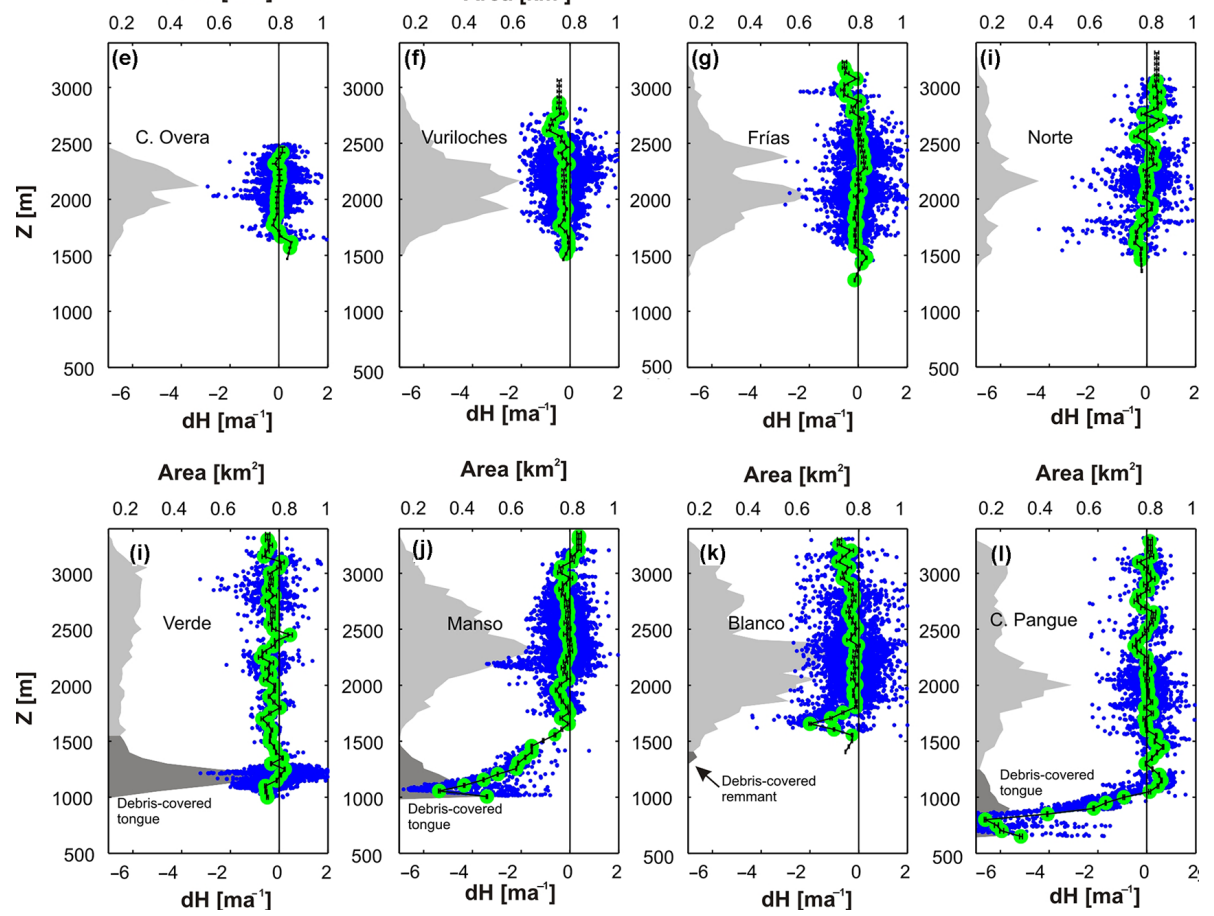

Figure 3. Elevation changes and hypsometry of Monte Tronador glaciers. Grey area shows the hypsometry of each glacier. The blue dots show all the elevation changes data for each glacier available after the curvature correction. The green dots represent the mean elevation change for each elevation band. The error bars (in black) are smaller than the green dots. For clear comparison all plots have the same scale and are sorted in glacier size in descending order. Glacier names are shown in each plot.

of elevation change $\left(\Delta h_{i}\right)$ is equal to the standard deviation $\left(\sigma_{\Delta h}\right)$ of the mean elevation change of its altitude band. The value of $\sigma_{\Delta h}$ can range from \pm 7 to $\pm 24 \mathrm{~m}$ depending on the altitude. Gardelle et al. (2013) suggested that this metric of error is rather conservative as the value of $\sigma_{\Delta h}$ contains both noise and a real geophysical signal.

The error $E \Delta h_{i}$ of the mean elevation change $\Delta h_{i}$ in each altitude band $i$ is then calculated according to standard principles of error propagation.

$$
E \Delta h_{i}=\frac{\sigma_{\Delta h}}{\sqrt{N_{\mathrm{eff}}}}
$$

where $N_{\text {eff }}$ represents the number of independent values in the altitude band, which is lower than the total number of values $\left(N_{\text {tot }}\right)$ since the latter are correlated spatially.

$N_{\text {eff }}=\frac{N_{\text {tot }} \cdot P_{\mathrm{s}}}{2 \cdot d}$,

where $P_{\mathrm{S}}$ is the pixel size $(30 \mathrm{~m})$ and $d$ is the distance of spatial autocorrelation $(71 \mathrm{~m})$, determined using Moran's I autocorrelation index on elevation differences off the glacier.

To calculate the error of the volume change for each glacier $\left(E d_{\mathrm{v}}\right), E \Delta h_{i}$ is converted to volume and summed.

$$
E d_{\mathrm{v}}=\sum\left(A_{i} \cdot E \Delta h_{i}\right)
$$

where $A_{i}$ is the area of each elevation band. We found a substantial increase in $E \Delta h$ for those altitude bands with fewer 


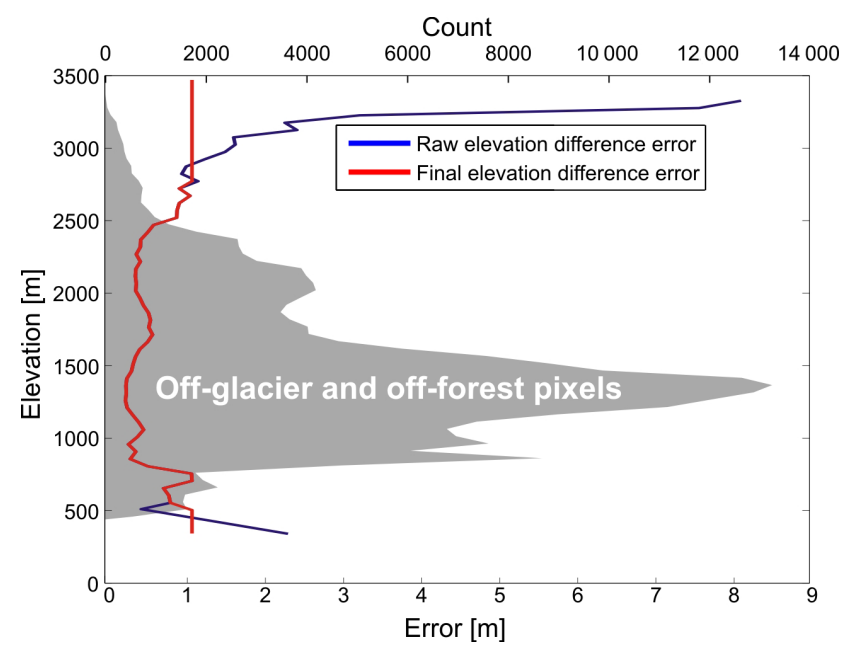

Figure 4. $E \Delta h$ distribution with altitude, the grey area represents the number of pixels off-glacier and off-forest in each elevation band. At very low (<500 m a.s.1.) and high (>2700 m a.s.1.) elevations the raw error increases, an artefact associated with the lower number of values available. The red line represents the $E \Delta h$ used to calculate the error of the geodetic mass balance estimation of Monte Tronador glaciers.

data (Fig. 4) due to the distribution of areas not covered by glaciers or forest. Above $2700 \mathrm{~m}$ most of the terrain is covered by glaciers and below $500 \mathrm{~m}$ it is mostly covered by forest. To prevent the overestimation of the error in the glaciercovered areas we used the maximum $E \Delta h$ in the interval 500 to $2700 \mathrm{~m}$, as $E \Delta h$ for those zones above $2700 \mathrm{~m}$ and below 500 m, i.e. $1.05 \mathrm{~m}$ (Fig. 4).

\subsubsection{Density assumption error assessment}

During the conversion from volume to mass, we assumed a density of $850 \pm 60 \mathrm{~kg} \mathrm{~m}^{-3}$ (Huss, 2013). The $\pm 60 \mathrm{kgm}^{-3}$ error on the density $(E \rho)$ assumption is included in the glacier mass balance by analysing the difference between using a density of 790 and $910 \mathrm{~kg} \mathrm{~m}^{-3}$ and our reference value of $850 \mathrm{~kg} \mathrm{~m}^{-3}$. The assumed $\pm 60 \mathrm{kgm}^{-3}$ density error represents a $16 \%$ change in the glacier mass balance.

To calculate the error of the total mass balance change $(E \bar{b})$ between February 2000 and 21 April 2012, $E d_{\mathrm{v}}$ and $E \rho$ were summed quadratically on the condition that they are completely independent.

$$
E \bar{b}=\sqrt{E d_{\mathrm{v}}^{2}+E \rho^{2}}
$$

\subsubsection{Seasonality correction error assessment}

Due to the scarcity of data on the seasonal mass balance of Monte Tronador glaciers, we conservatively assumed that the seasonality correction has an error $(E s)$ of $100 \%$ (i.e. $\pm 1 \mathrm{~m}$ w.e.). This error is summed quadratically to $E \bar{b}$ in order to calculate the error of the annual glacier-wide mass bal- ance for each glacier $\left(E \overline{b_{\mathrm{a}}}\right)$.

$$
E \overline{b_{\mathrm{a}}}=\sqrt{E \bar{b}^{2}+E s^{2}}
$$

\subsection{Analysis of regional climate variability and trends}

To put the observed glacier changes into the context of recent climate variations in the region, we analysed precipitation and temperature records derived from six surface stations located in the northern Patagonian Andes (Table 3). In each case, the temperature (precipitation) observations were first converted to anomalies by subtracting (dividing) these values with their long-term monthly means and then averaged to calculate regionally representative temperature and precipitation series for the 1931-2015 period. To evaluate the representativeness of the regional series, we compared the temperature and precipitation series with those derived from the closest stations to Monte Tronador but only available for a shorter period (Los Alerces and La Almohadilla stations; Table 3).

\section{Results}

\subsection{Glacier surface elevation changes}

The map of glacier elevation changes (Fig. 5) shows larger ice thinning at lower elevations and smaller thinning to slight thickening at higher elevations. The lower debriscovered tongues of Casa Pangue and Manso glaciers show the greatest losses of ice between 2000 and 2012, i.e. $-94 \pm 0.6 \mathrm{~m}$ (mean of $-35 \pm 0.5 \mathrm{~m}$ ) and $-85 \pm 0.6 \mathrm{~m}$ (mean of $-46 \pm 0.5 \mathrm{~m}$ ), respectively. Both glaciers show a considerable retreat during the 12 years assessed in this study (Table 4). On the contrary, the low-elevation debris-covered tongue of Verde glacier shows almost no change (mean of $-0.6 \pm 0.5 \mathrm{~m}$ ). The elevation change map of this debriscovered tongue shows an almost circular area of decreased elevation of $-35 \pm 0.6 \mathrm{~m}$ followed (in the sense of glacier flow) by a similar sized area of increased height of $35 \pm 0.6 \mathrm{~m}$ (thick black arrow in Fig. 5). Although akin to an artefact, this feature corresponds to advection by ice flow of a pile of debris due to a rock avalanche, which has lain on the surface of the glacier since at least 1981. The distance between the positive and negative peaks is $270-290 \mathrm{~m}$, which is similar to the displacement of the rock avalanche trace measured from the 2000 Landsat image to the 2012 Pléiades image, corresponding to a mean annual surface velocity of $23 \mathrm{~m} \mathrm{a}^{-1}$ over these 12 years. At this location, Ruiz et al. (2015) calculated a surface speed of $20-25 \mathrm{~m} \mathrm{a}^{-1}$ for the year 2012 .

\subsection{Glacier area change and mass balance}

Table 4 shows the area and ice volume changes and glacierwide mass balance for each glacier. The total area of Monte 
Table 3. The surface stations used to create the regional climate series. $\mathrm{CH}$ is Chile, AR is Argentina, $\mathrm{T}$ is temperature, $\mathrm{P}$ is precipitation. *1 La Almohadilla is the closest temperature record to Monte Tronador. *2 Los Alerces the closest precipitation record to Monte Tronador.

\begin{tabular}{lrrrl}
\hline Station & Latitude $\left(^{\circ}\right)$ & Longitude $\left(^{\circ}\right)$ & Elevation $(\mathrm{m})$ & Variable \\
\hline Temuco (CH) & -38.75 & -72.63 & 114 & $\mathrm{~T} \& \mathrm{P}$ \\
Valdivia (CH) & -39.63 & -73.08 & 19 & $\mathrm{~T} \& \mathrm{P}$ \\
Osorno (CH) & -40.75 & -73.06 & 65 & $\mathrm{~T} \& \mathrm{P}$ \\
Puerto Montt (CH) & -41.43 & -73.11 & 90 & $\mathrm{~T} \& \mathrm{P}$ \\
Bariloche (AR) & -41.15 & -71.16 & 840 & $\mathrm{~T} \& \mathrm{P}$ \\
Esquel (AR) & -42.93 & -71.15 & 785 & $\mathrm{~T} \& \mathrm{P}$ \\
La Almohadilla (AR)*1 & -41.2 & $-71-78$ & 1420 & $\mathrm{~T}$ \\
Los Alerces (AR)*2 & -41.36 & -71.73 & 772 & $\mathrm{P}$ \\
\hline
\end{tabular}

Table 4. Area, volume and mass balance change of Monte Tronador glaciers (2000-2012), with their corresponding error estimation. See Appendix A for a detailed description of these calculations.

\begin{tabular}{lrrrrrrrr}
\hline Glacier & $\begin{array}{r}\text { Area in } \\
2000\left(\mathrm{~km}^{2}\right)\end{array}$ & $\begin{array}{r}\text { \% Area } \\
\text { change }\end{array}$ & $\begin{array}{r}\mathrm{d} V \\
\left(\mathrm{~km}^{3}\right)\end{array}$ & $E d_{\mathrm{v}}$ & $\begin{array}{l}\bar{b} \\
(\mathrm{~m} \text { w.e. })\end{array}$ & $E \bar{b}$ & $\begin{array}{c}\overline{b_{\mathrm{a}}} \\
\left(\mathrm{m} \mathrm{w.e.} \mathrm{a}^{-1}\right)\end{array}$ & $E \overline{b_{\mathrm{a}}}$ \\
\hline Mistral & 1.5 & -10.1 & -0.015 & 0.001 & -7.5 & 0.9 & -0.54 & 0.11 \\
Peulla & 2.0 & -4.5 & -0.004 & 0.002 & -1.5 & 0.7 & -0.04 & 0.10 \\
Alerce & 2.4 & -3.0 & -0.007 & 0.002 & -2.3 & 0.7 & -0.11 & 0.10 \\
Parra & 2.5 & -4.0 & -0.017 & 0.002 & -5.3 & 0.6 & -0.35 & 0.10 \\
Norte & 3.0 & -0.01 & 0.002 & 0.003 & 0.7 & 0.8 & 0.14 & 0.10 \\
C. Overa & 3.2 & -0.1 & -0.001 & 0.003 & -0.4 & 0.7 & 0.05 & 0.10 \\
C. Pangue & 6.0 & -2.9 & -0.037 & 0.005 & -4.5 & 0.7 & -0.29 & 0.10 \\
Vuriloches & 6.4 & -0.01 & -0.020 & 0.006 & -2.6 & 0.7 & -0.13 & 0.10 \\
Frías & 6.7 & -0.3 & 0.003 & 0.006 & 0.3 & 0.7 & 0.11 & 0.10 \\
Verde & 6.7 & -1.2 & -0.017 & 0.004 & -2.0 & 0.5 & -0.08 & 0.09 \\
Manso & 9.6 & -5.2 & -0.085 & 0.009 & -7.1 & 0.9 & -0.50 & 0.11 \\
Blanco & 10.7 & -0.7 & -0.039 & 0.010 & -3.1 & 0.8 & -0.17 & 0.10 \\
\hline
\end{tabular}

Tronador glaciers decreased by $2 \%$ between 2000 and 2012 at a rate of $-0.1 \mathrm{~km}^{2} \mathrm{a}^{-1}$. Monte Tronador glaciers lost a total of $-0.22 \mathrm{~km}^{3}$ of ice, which represents a mass balance of $-3.1 \mathrm{~m}$ w.e. (between mid-February 2000 and 21 April 2012) at a rate of $-0.17 \mathrm{~m}$ w.e. $\mathrm{a}^{-1}$ (Table 4 ).

Manso, Blanco and Casa Pangue valley glaciers are the ones that lost the most volume in the last 12 years, with $-0.085 \pm 0.01,-0.039 \pm 0.01$ and $-0.037 \pm 0.01 \mathrm{~km}^{3}$, respectively. The largest volume losses of the Manso and Casa Pangue glaciers are concentrated in their lower debriscovered tongues. The mean ice-thickness change of Manso glacier in its accumulation area is $-0.10 \mathrm{~m} \mathrm{a}^{-1}$ and it decreases to $-2.71 \mathrm{~m} \mathrm{a}^{-1}$ in its ablation zone (maximum thinning rate of $-5.35 \pm 0.03 \mathrm{~m} \mathrm{a}^{-1}$ between 1050 and $1100 \mathrm{~m}$ ). Casa Pangue shows almost zero elevation change in its accumulation area (mean of $-0.06 \mathrm{~m} \mathrm{a}^{-1}$ ) and the highest thinning rate $\left(-6.88 \pm 0.06 \mathrm{~m} \mathrm{a}^{-1}\right)$ of all Monte Tronador glaciers in its ablation area. Meanwhile, Blanco glacier shows a moderate ice thickness loss along its entire surface (mean of $-0.7 \mathrm{~m} \mathrm{a}^{-1}$ ). On the contrary, Verde glacier shows an almost zero mass balance over the 2000-2012 pe$\operatorname{riod}\left(-0.09 \pm 0.09\right.$ m w.e. $\left.\mathrm{a}^{-1}\right)$.
Due to their small sizes, the Mistral and Parra glaciers show relatively small changes in ice volume $\left(-0.015 \pm 0.001 \mathrm{~km}^{3}\right.$ and $0.017 \pm 0.002 \mathrm{~km}^{3}$, respectively). Nevertheless, Mistral shows the most negative mass balance $\left(-0.54 \pm 0.11 \mathrm{~m}\right.$ w.e. $\left.\mathrm{a}^{-1}\right)$ and Parra the third most negative mass balance $\left(-0.35 \pm 0.10 \mathrm{mw}^{\text {w.e. }} \mathrm{a}^{-1}\right)$ among all Monte Tronador glaciers. Mistral shows the highest relative area decrease of all Monte Tronador glaciers. The five other mountain glaciers (Alerce, Castaño Overa, Vuriloches, Norte Peulla and Frías) show slightly negative to slightly positive mass balances ( -0.1 to $0.14 \mathrm{~m}$ w.e. $\mathrm{a}^{-1}$; Table 4$)$ and minor areal changes.

\subsection{Climate variability and trends}

The regionally averaged series of summer temperature and annual precipitation anomalies indicate that the northern Patagonia region has experienced an overall warming combined with a drying trend during the last eight decades (1931-2015; Fig. 6a and b). The temperature and precipitation stations located closest to Monte Tronador cover a shorter time span (1995-2015) but show the same variability as their corresponding regional series (Fig. 6a and b). 


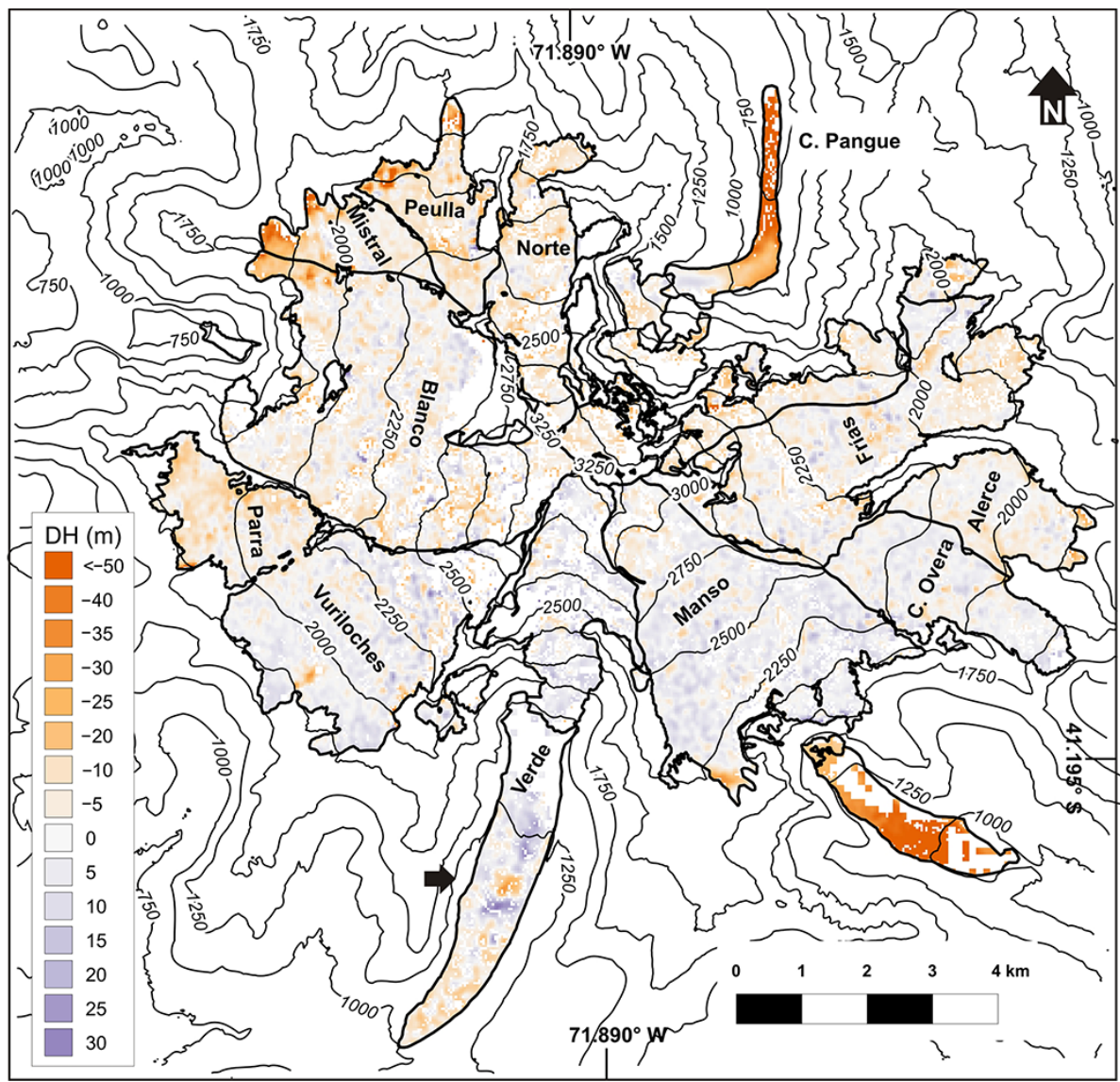

Figure 5. Elevation change map of Monte Tronador glaciers for the period 2000-2012. The thick black arrow shows the positive/negative elevation change associated with the advection of the rock avalanche deposited onto the surface of Verde glacier.

The warming and drying trends observed in this region are coherent with the long-term retreat of glaciers reported for the northern Patagonian Andes in the last century (Fig. 6c). Within these long-term climate trends, however, we also observed important intra- to multi-decadal variations that seem to have also affected the glacier fluctuations regionally. Probably the clearest pattern is the considerably colder summertime temperatures between the late 1960s and the late 1970s (Fig. 6a), and the marked shift towards warmer temperatures afterwards. The lower temperatures and slightly larger precipitations in the late 1970s were likely responsible for the generalized re-advances of Monte Tronador and others northern Patagonian glaciers in that decade (Leclercq et al., 2012; Masiokas et al., 2009; Ruiz et al., 2012; see also Fig. 6c). After 1980 summertime temperatures increased markedly and have remained above the long-term mean since then. A moderate increase in temperatures can be observed in the last decade of the records, which probably contributed to further melting at Tronador and elsewhere in this region (Fig. 6a). Precipitation, in contrast, has varied considerably over the last 30-40 years but in general it has not reached the ex- tremely high values observed in the first decades of the series (Fig. 6b).

\section{Discussion}

\subsection{Bias corrections and error assessment}

DEM differencing is increasingly used to derive geodetic mass balance of glaciers. Nevertheless, it is important to identify and correct possible biases due to misalignments among DEMs (Berthier et al., 2004; Nuth and Kääb, 2011) and also apparent elevation bias (i.e. curvature correction; Gardelle et al., 2013) to derive realistic values. Our misalignment correction (Table 2) shows that there was a minor shift among DEMs of $\sim 26 \%$ pixel size.

The curvature correction improved the residuals by $30 \%$ in the RMSE and STD and decreased the bias closer to zero (Fig. 2c). $E \Delta h$ by elevation band with a maximum value of $1.05 \mathrm{~m}$ shows that the results are robust, even for the smaller glaciers (Table 4$)$. Our mass balance error $\left(\sim 0.1 \mathrm{~m}\right.$ w.e. $\left.\mathrm{a}^{-1}\right)$ is in the same range as other geodetic mass balance studies (Cogley, 2009; Thibert et al., 2008; Zemp et al., 2010). The 

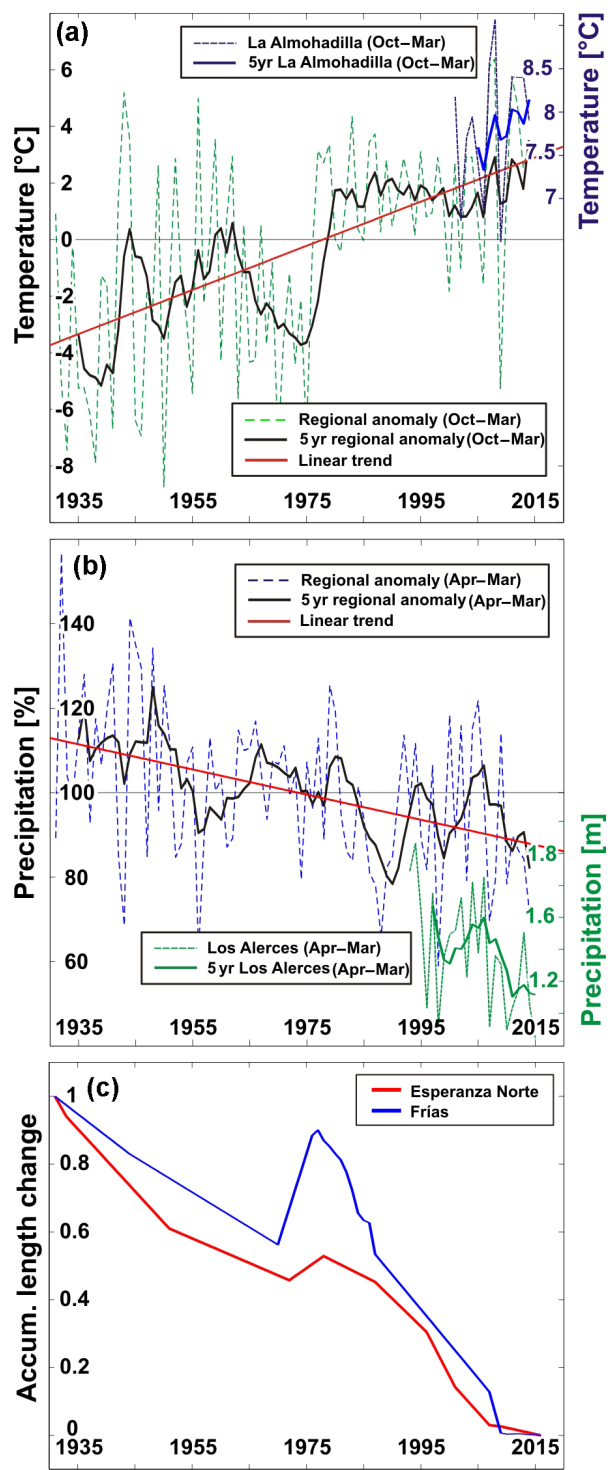

Figure 6. (a) Warm season (October-March) temperature anomaly series derived from six selected stations in the northern Patagonian region. The linear trend and a 5-year moving average are shown to highlight the low-frequency patterns in this series. The temperature record in La Almohadilla, the closest temperature record to Monte Tronador is also shown. (b) Same as (a), but for April to March precipitation variations in this region. The precipitation record in Los Alerces, the closest precipitation record to Monte Tronador is also shown (c) Length changes of Frías and Esperanza Norte glaciers, updated from Leclercq et al., 2012; Ruiz et al., 2012. Esperanza Norte is also a clean ice glacier located ca. $100 \mathrm{~km}$ south of Tronador (Ruiz et al., 2012). Note the overall retreating pattern is only interrupted by re-advances in the late 1970s.

rather small distance of autocorrelation of the error $(70.8 \mathrm{~m}$, equivalent to 2 pixels) indicates that the errors exhibit a weak spatial correlation and are mostly associated with the noise in the SRTM-X. It is important to note that since sharp relief features are not as well depicted in SRTM-X as in PLEI, el- evation changes closer to strong changes in slope area, like the front of Castaño Overo or Blanco glaciers, can produce anomalous values. A possible solution could be to discard pixels with high absolute curvature.

Our main sources of systematic errors in the mass balance calculation of Monte Tronador glaciers were associated with (1) elevation change estimates and (2) the seasonality correction. The first factor is mainly due to the noise in SRTM-X. Nevertheless, a maximum $E \Delta h$ of $1.05 \mathrm{~m}$ and an RMSE of $2.7 \mathrm{~m}$ indicate a good correspondence between DEMs. The second most important source of error is linked to the limited knowledge of seasonal mass balance of Monte Tronador glaciers. For Alerce glacier, the $1 \mathrm{~m}$ w.e. seasonal correction represents a change of $45 \%$ in the annual mass balance (from -0.18 to $-0.1 \mathrm{~m}$ w.e. $\mathrm{a}^{-1}$ ). Due to the high ablation and accumulation rate of these glaciers, the seasonality correction must be taken into account. Nevertheless, due to the lack of mass balance measurement in the rest of the glaciers and the difference in the temperature anomalies between the year 2000 and the ones used to assess the correction (Fig. 6a) we assume a conservative $100 \%$ error in this correction. Direct measurements of mass balance on various glaciers combined with mass balance models (Huss et al., 2008) could help to improve the correction applied here and its inherent error.

\subsection{Mass balance changes differences among Monte Tronador glaciers}

With the exception of Mistral and Parra, mountain glaciers which do not descend below the $1600-1700 \mathrm{~m}$ a.s.l. bedrock cliff have mass balance values close to zero over the 2000 2012 period (i.e. from -0.13 to $0.14 \mathrm{~m}$ w.e. $\mathrm{a}^{-1}$; Table 4 ). These glaciers also have minor areal changes, from -3 to $0 \%$, which again suggests that the geometry of these glaciers is close to equilibrium with current climate. The exceptionally high mass balance loss of Mistral and Parra $(-0.54$ and $-0.35 \mathrm{~m}$ w.e. $\mathrm{a}^{-1}$ ) could be explained by the small elevation range of these glaciers (580 and $750 \mathrm{~m}$, respectively) compared with the rest of the mountain glaciers $(>800$ to $1900 \mathrm{~m}$ ). The lower elevation ranges could translate to less accumulation and smaller AAR (accumulation area ratio; i.e. the ratio between accumulation area and glacier area) and hence more negative mass balances.

Similar to other glaciers in the northern Patagonian Andes (Paul and Mölg, 2014), we found that the valley glaciers of Monte Tronador, especially those at lower elevations, are shrinking at rapid rates. At the debris-covered tongue of Manso glacier, we found one of the highest thinning rates of Monte Tronador, which results in the negative glacierwide mass balance of this glacier. Sometime in the 1990s the proglacial lake started to form in front of the glacier tongue and has been growing since then. However, it was not until 2009, when a glacier lake outburst flood event occurred (Worni et al., 2012), that a straight calving front developed on this glacier. The acceleration of ice flow at the glacier front 
(Ruiz et al., 2015) indicates that calving has been highly active in recent years and could be one of the causes for the high thinning rates of this debris-covered tongue.

Bown and Rivera (2007) analysed the elevation change along the central flow line of the debris-covered tongue of Casa Pangue (from 700 to 1050 m a.s.l.; Fig. 5 in Bown and Rivera, 2007) between 1968 and 1998. They found an acceleration in mean (maximum) thinning rate from 1968-1981 to $1981-1998$ of more than $100 \%$, from $-1.2 \pm 1.1 \mathrm{~m} \mathrm{a}^{-1}$ $(-2.9 \pm 1.1)$ to $-3.6 \pm 0.6 \mathrm{~m} \mathrm{a}^{-1}\left(-5.3 \pm 0.6 \mathrm{~m} \mathrm{a}^{-1}\right)$, respectively. They also noticed that this increase in the thinning rate was accompanied by an enhanced frontal retreat of the glacier. Analysing the debris-covered tongue of this glacier alone (between 600 and $1050 \mathrm{~m}$ a.s.l.), we found a mean thinning rate of $-4.1 \pm 0.1 \mathrm{~m} \mathrm{a}^{-1}$ and a maximum thinning rate of $-6.6 \pm 0.1 \mathrm{~m} \mathrm{a}^{-1}$ between 2000 and 2012. This shows that the rate of thinning is still accelerating at this site compared to 1981-1998, but at a slower rate $(\sim 30 \%)$, which could be related to the thickening of the surface debris layer. Bown and Rivera (2007) linked the thinning along the central flow line with the increase in air temperature at high elevation and a regional decrease in precipitation. Nevertheless, an increase in the thinning rate cannot be directly attributed to a more negative surface mass balance, since a reduction in ice flux could also be contributing to the thinning (e.g. Berthier and Vincent, 2012).

The only exception to the general shrinkage of valley glaciers in Monte Tronador is the Verde glacier. The neutral mass balance of this glacier is in agreement with the minor changes in area $(-1.2 \%)$ and the $0 \mathrm{~m} \mathrm{a}^{-1}$ frontal retreat rate observed between 2000 and 2012. The small area change is concentrated in the accumulation area associated with the appearance of the headwall. We hypothesize that a high ice flow from the accumulation area and a thick debris layer covering the ablation area are favouring the neutral mass balance of this glacier in an unfavourable regional climate (see Sect. 5.4). The accumulation area of this glacier is very steep, and the ice is flowing at a maximum rate of $390 \mathrm{~m} \mathrm{a}^{-1}$, which is the highest surface velocity measured at Monte Tronador glaciers (Ruiz et al., 2015). The ice from the accumulation area is still flowing uninterrupted to the debris-covered tongue, which is moving with a surface velocity between 10 and $35 \mathrm{~m} \mathrm{a}^{-1}$. Although we do not have ice thickness and surface mass balance data, the evidence that the debris-covered tongue is still moving at an appreciable rate could imply that the ice flux is compensating the mass loss due to surface mass balance in this glacier. The presence of the rock avalanche deposit over the surface of the debriscovered tongue (Ruiz et al., 2015) indicates that the debris layer is quite thick, supporting our explanation.

The frontal retreat rate of $0 \mathrm{~m} \mathrm{a}^{-1}$ between 2000 and 2012 and the fact that the snout of Verde glacier is still in contact with its Little Ice Age moraine (Ruiz et al., 2015) contrasts with a frontal retreat rate of $-17 \mathrm{~m} \mathrm{a}^{-1}$ for this glacier between 1961 and 1997 (Rivera et al., 2002; WGMS, 2015).
There is no available information about the source images or the accuracy of the measurements used to retrieve the frontal variation of this glacier (Rivera et al., 2002; WGMS, 2015), so we do not have enough data to assess whether there was an advance of this glacier after 1997 or not.

\subsection{Mass balance of Monte Tronador glaciers in a regional perspective}

The shrinkage of Monte Tronador glaciers, both in volume and in area, is in agreement with the general thinning and recession of glaciers observed in the Southern Andes and elsewhere (Bown and Rivera, 2007; Gardner et al., 2013; Masiokas et al., 2009; Paul and Mölg, 2014; Zemp et al., 2015). In the last two decades, negative mass balances between $-0.6 \pm 0.4 \mathrm{~m}$ w.e. $\mathrm{a}^{-1}(1993-2003)$ and $-0.7 \pm 0.2 \mathrm{~m}$ w.e. $\mathrm{a}^{-1}$ (2003-2012) have been observed in South America and the sub-Antarctic islands (Mernild et al., 2015). Examining latitudinal variations, Mernild et al. (2015) found a decrease in the rate of mass loss from the tropical Andes to the sub-Antarctic islands for both decades. Specifically for the period 2003-2012 they showed that the mass balance rate was more negative in the north $\left(-0.97 \mathrm{~m}\right.$ w.e. $\mathrm{a}^{-1}$ in the tropical Andes; $-0.77 \mathrm{~m}$ w.e. $\mathrm{a}^{-1}$ in the Central Andes) than in the south of the Andes $\left(-0.29 \mathrm{~m}^{-e .} \mathrm{a}^{-1}\right.$ in Andes of Tierra del Fuego and $-0.06 \mathrm{~m}$ w.e. $\mathrm{a}^{-1}$ in the subAntarctic islands). Since there were no data on glacier-wide mass balance for the northern Patagonian Andes, our results contribute to filling in this gap in the mass balance information. The mass balance for all Monte Tronador glaciers $\left(-0.17 \pm 0.11 \mathrm{~m}\right.$ w.e. $\left.\mathrm{a}^{-1}\right)$ has the same order of magnitude as the mass loss in the Andes of Tierra del Fuego. This could imply that mass loss in northern Patagonian Andes is more related to the changes observed further south than those in the tropical Central Andes.

Willis et al. (2012a, b) found an area averaged elevation change for the period 2000-2012 of $-1.8 \pm 0.1$ and $-1.3 \pm 0.1 \mathrm{ma}^{-1}$ of ice for the southern and northern Patagonian ice fields, respectively. Using the same density conversion as in our study $\left(850 \mathrm{~kg} \mathrm{~m}^{-3}\right)$, the ice field-wide mass balance for the two ice fields were -1.5 and $-1.1 \mathrm{~m}$ w.e. $\mathrm{a}^{-1}$, respectively. These values are 1 order of magnitude larger (more negative) than the values reported for the rest of the glaciers in the Southern Andes and do not follow the decreasing north-south trend found for smaller glaciers by Mernild et al. (2015). Schaefer et al. (2015) suggested that calving fluxes, which apparently increased in the last decade, are probably the cause of the high mass loss of the southern Patagonian ice field, which according to their mass balance model showed an overall positive surface mass balance between 1975 and 2011. 


\subsection{Climate and mass balance changes}

Our analysis of reliable and regionally representative climate series shows a long-term tendency towards warmer and drier climatic conditions during the last eight decades in the northern Patagonian Andes. This finding seems to explain the general ice mass loss detected at Monte Tronador, and is in line with previous glaciological studies in the northern Patagonian Andes (Bown and Rivera, 2007; Masiokas et al., 2008; Rivera et al., 2002). Within this trend, several features also appear to be related to the observed glacier behaviour in this region. The much colder and moderately wetter period observed around the 1970s immediately precedes the last recorded glacier advances in northern Patagonian Andes, which peaked between 1976 and 1978 (Leclercq et al., 2012; Masiokas et al., 2010; Ruiz et al., 2012). In agreement with a large-scale climate shift in 1976-1977, which has been extensively studied and documented in other regions (Giese et al., 2002), climate conditions in northern Patagonia became markedly warmer after this cold interval. According to our records (Fig. 6a and b), during the last 40 years, the region has not experienced dramatic trends in temperature nor precipitation. Instead, conditions have been different (i.e. warmer, and likely drier) to those experienced before the 1970s. The fact that higher elevation glaciers at Monte Tronador are only showing minor thinning, whereas their lower neighbours show the largest retreat rates, suggests that the upper glaciers have probably already adjusted to these new climate conditions but the lower glaciers have not. Paul and Mölg (2014) found retreat rates that support this hypothesis, with a decrease in the rate of glacier area change from $-16 \mathrm{~km}^{2} \mathrm{a}^{-1}$ (1984-2000) to $-4 \mathrm{~km}^{2} \mathrm{a}^{-1}$ (2000-2011). The frontal fluctuation records of Frías and Esperanza Norte glaciers (Fig. 6c; the longest and most detailed length fluctuation series available in the northern Patagonian Andes) also show a decrease in the retreat rate between 1980s-2000s and 2000s-2010s. Our almost neutral mass balance estimation during the last decade also implies that most glaciers in Monte Tronador are probably close to equilibrium with the present climate.

\section{Conclusions}

Here we present, for the first time, an elevation change map and glacier-wide mass balance data for the Monte Tronador glaciers in the northern Patagonian Andes. During the period 2000 to 2012 these glaciers lost mass at a mean rate of $-0.17 \mathrm{~m}$ w.e. $\mathrm{a}^{-1}$ (range of -0.54 to $0.14 \mathrm{mw}^{-e .} \mathrm{a}^{-1}$ ). This value is similar to the mass loss of glaciers monitored in Tierra del Fuego, but far less negative than observed in the tropical Central Andes and the large Patagonian ice fields.
Regional climate (warm season temperatures and annual precipitation) records indicate overall trends towards warmer and drier conditions over the past eight decades. These trends may at least partly explain the generalized glacier shrinkage observed throughout this region in the last century. Interestingly, however, these records also show that after ca. 1980 climate conditions have remained relatively stable, but substantially warmer than pre-1980 levels.

As the response of individual glaciers to a given climate change depends on the morphology and dynamic of each glacier, these new climate conditions probably affected different glaciers in different ways. With a few exceptions, at Monte Tronador we observed that the valley glaciers that descend below the bedrock cliff and have debris-covered tongues lost mass at higher rates than mountain glaciers located at higher altitudes. This suggests that the upper glaciers have already reached a dynamic equilibrium with current climate conditions, whereas the larger low elevation glacier tongues have not and will probably continue to shrink until they adjust to the present climate. We also hypothesize that the almost neutral mass balance of the large, low-lying debris-covered Verde glacier is related to a high ice flux coming from the accumulation area combined with a thick debris layer in the ablation area. In the case of Mistral and Parra glaciers, we associate their high negative mass balance with their narrow elevational ranges.

Further research is needed to validate these hypotheses and test, through modelling and direct field observations, the glacier-climate relationships at Monte Tronador and other glaciated peaks in this region. The mass balance and hydroclimatology monitoring programme recently initiated at Monte Tronador (Ruiz et al., 2015) has already shown promising results and could help elucidate these and several other poorly known glaciological issues in the northern Patagonian Andes.

\section{Data availability}

Mass balance data for Monte Tronador glaciers are presented in Table 4. Elevation changes map for Monte Tronador glaciers between 2000 and 2012 and other data sets used in the article are available upon request by email to the first author. 
Appendix A: Estimation of the volume change and the mass balance of Tronador glaciers from the elevation change map

From the mean elevation change $\left(\mathrm{d} h_{n}\right)$ and the area covered $S_{n}$ by each elevation band, we calculate the total volume change $\mathrm{d} V$ (Eq. A1).

$\mathrm{d} V=\sum S_{n} \cdot \mathrm{d} h_{n}\left[\mathrm{~m}^{3}\right]$

Then we calculate the glacier mass balance $(B)$ using the density conversion factor $\left(\rho_{i}\right)$ of $850 \pm 60 \mathrm{~kg} \mathrm{~m}^{-3}$.

$B=\rho_{i} \cdot \mathrm{d} V \quad\left[\mathrm{~m}^{3}\right.$ w.e. $]$
Finally the glacier-wide mass balance $\bar{b}$ (Eq. A3) and the mean annual glacier-wide mass balance $\overline{b_{\mathrm{a}}}$ (Eq. A4) were obtained.

$\bar{b}=\frac{B}{S_{\text {glacier }}}$ [mw.e. $]$,

where $S_{\text {glacier }}$ is the area of each glacier in 2000 and

$\overline{b_{\mathrm{a}}}=\frac{\bar{b}+s_{\text {corr }}}{\mathrm{d} t}\left[\right.$ mw.e. $\left.\mathrm{a}^{-1}\right]$

where $s_{\text {corr }}$ is the seasonality correction ( $1 \mathrm{~m} \mathrm{w.e.),} \mathrm{and} \mathrm{d} t$ the time span. 
Competing interests. The authors declare that they have no conflict of interest.

Acknowledgements. We would like to acknowledge the support from Ministerio de Ambiente y Desarrollo Sustentable de Argentina (Inventario Nacional de Glaciares), Agencia de Promoción Científica (projects PICT 2010-1438; PICT 2014-1794) and CONICET for funding. JICA (Japan International Cooperation Agency) also provided funding and equipment which were critical for the completion of this work. Etienne Berthier acknowledges support from the French Space Agency (CNES) through the TOSCA programme and from the Programme National de Telédétection Spatiale (PNTS). Maximiliano Viale acknowledges supports from FONDECYT 11151009. Pléiades images were provided at no cost by Airbus Defense and Space through the Pléiades User Group initiative. Administración de Parques Nacionales kindly provided permission and logistical assistance to work at Monte Tronador inside Parque Nacional Nahuel Huapi. The GNNS measures used in this study could not have been conducted without the valuable field knowledge and collaboration provided by Mauricio Cadillo, Ernesto Corvalán and Juan Pablo Scarpa. The fieldwork would have been much harder without the hospitality of Nicolas Betinelli and the staff of Refugio Otto Meiling. The constructive comments and suggestions from the handling editor, S. J. Khalsa, and one anonymous referee significantly improved the manuscript and are greatly appreciated.

Edited by: M. Tedesco

Reviewed by: S. J. Khalsa and one anonymous referee

\section{References}

Berthier, E. and Vincent, C.: Relative contribution of surface massbalance and ice-flux changes to the accelerated thinning of Mer de Glace, French Alps, over 1979-2008, J. Glaciol., 58, 501-512, doi:10.3189/2012JoG11J083, 2012.

Berthier, E., Arnaud, Y., Baratoux, D., Vincent, C., and Remy, F.: Recent rapid thinning of the "Mer de Glace" glacier derived from satellite optical images, Geophys. Res. Lett., 31, L17401, doi:10.1029/2004GL020706, 2004.

Berthier, E., Arnaud, Y., Kumar, R., Ahmad, S., Wagnon, P., and Chevallier, P.: Remote sensing estimates of glacier mass balances in the Himachal Pradesh (Western Himalaya, India), Remote Sens. Environ., 108, 327-338, doi:10.1016/j.rse.2006.11.017, 2007.

Berthier, E., Vincent, C., Magnússon, E., Gunnlaugsson, Á. p., Pitte, P., Le Meur, E., Masiokas, M., Ruiz, L., Pálsson, F., Belart, J. M. C., and Wagnon, P.: Glacier topography and elevation changes derived from Pléiades sub-meter stereo images, The Cryosphere, 8, 2275-2291, doi:10.5194/tc-8-2275-2014, 2014.

Bown, F. and Rivera, A.: Climate changes and recent glacier behaviour in the Chilean Lake District, Glob. Planet. Change, 59, 79-86, doi:10.1016/j.gloplacha.2006.11.015, 2007.

Cogley, J. G.: Geodetic and direct mass-balance measurements: comparison and joint analysis, Ann. Glaciol., 50, 96-100, 2009.

Cogley, J. R., Hock, R., Rasmussen, L. A., Arendt, A. A., Bauder, A., Braithwaite, R. J., Jansson, P., Kaser, G., Möller, M., Nichol- son, L., and Zemp, M.: Glossary of Glacier Mass Balance and Related Terms, UNESCO-IHP, Paris, available at: http:// unesdoc.unesco.org/images/0019/001925/192525E.pdf (last access: 1 February 2015), 2011.

Dall, J., Madsen, S. N., Keller, K., and Forsberg, R.: Topography and penetration of the Greenland Ice Sheet measured with Airborne SAR Interferometry, Geophys. Res. Lett., 28, 1703-1706, doi:10.1029/2000GL011787, 2001.

Davies, B. J. and Glasser, N. F.: Accelerating shrinkage of Patagonian glaciers from the Little Ice Age ( AD 1870) to 2011, J. Glaciol., 58, 1063-1084, doi:10.3189/2012JoG12J026, 2012.

Farr, T. G., Rosen, P. A., Caro, E., Crippen, R., Duren, R., Hensley, S., Kobrick, M., Paller, M., Rodriguez, E., Roth, L., Seal, D., Shaffer, S., Shimada, J., Umland, J., Werner, M., Oskin, M., Burbank, D., and Alsdorf, D.: The Shuttle Radar Topography Mission, Rev. Geophys., 45, RG2004, doi:10.1029/2005RG000183, 2007.

Gardelle, J., Berthier, E., and Arnaud, Y.: Impact of resolution and radar penetration on glacier elevation changes computed from DEM differencing, J. Glaciol., 58, 419-422, doi:10.3189/2012JoG11J175, 2012.

Gardelle, J., Berthier, E., Arnaud, Y., and Kääb, A.: Region-wide glacier mass balances over the Pamir-Karakoram-Himalaya during 1999-2011, The Cryosphere, 7, 1263-1286, doi:10.5194/tc7-1263-2013, 2013.

Gardner, A. S., Moholdt, G., Cogley, J. G., Wouters, B., Arendt, A. A., Wahr, J., Berthier, E., Hock, R., Pfeffer, W. T., Kaser, G., Ligtenberg, S. R. M., Bolch, T., Sharp, M. J., Hagen, J. O., van den Broeke, M. R., and Paul, F.: A Reconciled Estimate of Glacier Contributions to Sea Level Rise: 2003 to 2009, Science, 340, 852-857, doi:10.1126/science.1234532, 2013.

Garreaud, R. D.: The Andes climate and weather, Adv. Geosci., 22, 3-11, doi:10.5194/adgeo-22-3-2009, 2009.

Giese, B. S., Urizar, S. C., and Fučkar, N. S.: Southern Hemisphere Origins of the 1976 Climate Shift, Geophys. Res. Lett., 29, 1-4, doi:10.1029/2001GL013268, 2002.

Hoffmann, J. and Walter, D.: How complementary are SRTM-X and-C band digital elevation models?, Photogramm. Eng. Remote Sens., 72, 261-268, 2006.

Hoskins, B. J. and Hodges, K. I.: A new perspective on Southern Hemisphere storm tracks, J. Clim., 18, 4108-4129, 2005.

Huss, M.: Density assumptions for converting geodetic glacier volume change to mass change, The Cryosphere, 7, 877-887, doi:10.5194/tc-7-877-2013, 2013.

Huss, M., Bauder, A., Funk, M., and Hock, R.: Determination of the seasonal mass balance of four Alpine glaciers since 1865, J. Geophys. Res.-Earth Surf., 113, F01015, doi:10.1029/2007JF000803, 2008.

Huss, M., Bauder, A., and Funk, M.: Homogenization of long-term mass-balance time series, Ann. Glaciol., 50, 198-206, 2009.

Intergovernmental Panel on Climate Change, Ed.: Climate Change 2013 - The Physical Science Basis: Working Group I Contribution to the Fifth Assessment Report of the Intergovernmental Panel on Climate Change, Cambridge University Press, Cambridge, available at: http://ebooks.cambridge.org/ref/ id/CBO9781107415324 (last access: 22 June 2016), 2013.

Jaber, W. A., Floricioiu, D., Rott, H., and Eineder, M.: Surface elevation changes of glaciers derived from SRTM and TanDEM-X 
DEM differences, in Geoscience and Remote Sensing Symposium (IGARSS), 2013 IEEE International, 1893-1896, 2013.

Kääb, A., Berthier, E., Nuth, C., Gardelle, J., and Arnaud, Y.: Contrasting patterns of early 21 st century glacier mass change in the Himalaya, Nature, 488, 495-498, doi:10.1038/nature11324, 2012.

Leclercq, P. W., Pitte, P., Giesen, R. H., Masiokas, M. H., and Oerlemans, J.: Modelling and climatic interpretation of the length fluctuations of Glaciar Frías (north Patagonian Andes, Argentina) 1639-2009 AD, Clim. Past, 8, 1385-1402, doi:10.5194/cp-81385-2012, 2012.

Lenaerts, J. T. M., van den Broeke, M. R., van Wessem, J. M., van de Berg, W. J., van Meijgaard, E., van Ulft, L. H., and Schaefer, M.: Extreme Precipitation and Climate Gradients in Patagonia Revealed by High-Resolution Regional Atmospheric Climate Modeling, J. Clim., 27, 4607-4621, doi:10.1175/JCLI-D-13-00579.1, 2014.

Masiokas, M. H., Villalba, R., Luckman, B. H., Lascano, M. E., Delgado, S. and Stepanek, P.: 20th-century glacier recession and regional hydroclimatic changes in northwestern Patagonia, Glob. Planet. Change, 60, 85-100, 2008.

Masiokas, M. H., Rivera, A., Espizua, L. E., Villalba, R., Delgado, S., and Aravena, J. C.: Glacier fluctuations in extratropical South America during the past 1000 years, Palaeogeogr. Palaeoclimatol. Palaeoecol., 281, 242-268, 2009.

Masiokas, M. H., Luckman, B. H., Villalba, R., Ripalta, A., and Rabassa, J.: Little Ice Age fluctuations of Glaciar Rio Manso in the north Patagonian Andes of Argentina, Quat. Res., 73, 96106,2010

Mernild, S. H., Beckerman, A. P., Yde, J. C., Hanna, E., Malmros, J. K., Wilson, R., and Zemp, M.: Mass loss and imbalance of glaciers along the Andes Cordillera to the sub-Antarctic islands, Glob. Planet. Change, 133, 109-119, doi:10.1016/j.gloplacha.2015.08.009, 2015.

Neckel, N., Braun, A., Kropácek, J., and Hochschild, V.: Recent mass balance of the Purogangri Ice Cap, central Tibetan Plateau, by means of differential X-band SAR interferometry, The Cryosphere, 7, 1623-1633, doi:10.5194/tc-7-1623-2013, 2013.

Nuth, C. and Kääb, A.: Co-registration and bias corrections of satellite elevation data sets for quantifying glacier thickness change, The Cryosphere, 5, 271-290, doi:10.5194/tc-5-271-2011, 2011.

Paul, F.: Calculation of glacier elevation changes with SRTM: is there an elevation-dependent bias?, J. Glaciol., 54, 945-946, doi:10.3189/002214308787779960, 2008.

Paul, F. and Mölg, N.: Hasty retreat of glaciers in northern Patagonia from 1985 to 2011, J. Glaciol., 60, 1033-1043, doi:10.3189/2014JoG14J104, 2014.

Rankl, M. and Braun, M.: Glacier elevation and mass changes over the central Karakoram region estimated from TanDEM-X and SRTM/X-SAR digital elevation models, Ann. Glaciol., 57, 273 281, doi:10.3189/2016AoG71A024, 2016.

Rignot, E., Echelmeyer, K., and Krabill, W.: Penetration depth of interferometric synthetic-aperture radar signals in snow and ice, Geophys. Res. Lett., 28, 3501-3504, 2001.

Rivera, A., Acuna, C., Casassa, G., and Bown, F.: Use of remotely sensed and field data to estimate the contribution of Chilean glaciers to eustatic sea-level rise, Ann. Glaciol., 34, 367-372, 2002.
Rodriguez, E., Morris, C. S., and Belz, J. E.: A global assessment of the SRTM performance, Photogramm. Eng. Remote Sens., 72, 249-260, 2006.

Ruiz, L. and Bodin, X.: Analysis and improvement of surface representativeness of high resolution Pléiades DEMs: Examples from glaciers and rock glaciers in two areas of the Andes, in: Geomorphometry for Geosciences, 223-226, Bogucki Wydawnictwo Naukowe, Adam Mickiewicz University in Poznań - Institute of Geoecology and Geoinformation, Poznań, Poland, 2015.

Ruiz, L., Masiokas, M. H., and Villalba, R.: Fluctuations of Glaciar Esperanza Norte in the north Patagonian Andes of Argentina during the past $400 \mathrm{yr}$, Clim. Past, 8, 1079-1090, doi:10.5194/cp-81079-2012, 2012.

Ruiz, L., Berthier, E., Masiokas, M., Pitte, P., and Villalba, R.: First surface velocity maps for glaciers of Monte Tronador, North Patagonian Andes, derived from sequential Pléiades satellite images, J. Glaciol., 61, 908-922, doi:10.3189/2015JoG14J134, 2015.

Schaefer, M., Machguth, H., Falvey, M., Casassa, G., and Rignot, E.: Quantifying mass balance processes on the Southern Patagonia Icefield, The Cryosphere, 9, 25-35, doi:10.5194/tc-9-252015, 2015.

Smith, R. B. and Evans, J. P.: Orographic Precipitation and Water Vapor Fractionation over the Southern Andes, J. Hydrometeorol., 8, 3-19, doi:10.1175/JHM555.1, 2007.

Stuefer, M., Rott, H., and Skvarca, P.: Glaciar Perito Moreno, Patagonia: climate sensitivities and glacier characteristics preceding the 2003/04 and 2005/06 damming events, J. Glaciol., 53, 3-16, 2007.

Surdyk, S.: Low microwave brightness temperatures in central Antarctica: observed features and implications, Ann. Glaciol., 34, 134-140, doi:10.3189/172756402781817464, 2002a.

Surdyk, S.: Using microwave brightness temperature to detect short-term surface air temperature changes in Antarctica: An analytical approach, Remote Sens. Environ., 80, 256-271, doi:10.1016/S0034-4257(01)00308-X, 2002b.

Thibert, E., Blanc, R., Vincent, C., and Eckert, N.: Glaciological and volumetric mass-balance measurements: error analysis over 51 years for Glacier de Sarennes, French Alps, J. Glaciol., 54, 522-532, 2008.

Viale, M. and Garreaud, R.: Orographic effects of the subtropical and extratropical Andes on upwind precipitating clouds, J. Geophys. Res.-Atmos., 120, 2014JD023014, doi:10.1002/2014JD023014, 2015.

Villalba, R., Leiva, J. C., Rubulls, S., Suarez, J., and Lenzano, L.: Climate, Tree-Ring, and Glacial Fluctuations in the Rio Frias Valley, Rio Negro, Argentina, Arct. Alp. Res., 22, 215, doi:10.2307/1551585, 1990.

Wang, D. and Kääb, A.: Modeling Glacier Elevation Change from DEM Time Series, Remote Sens., 7, 10117-10142, doi:10.3390/rs70810117, 2015.

WGMS: Global Glacier Change Bulletin No. 1 (2012-2013), edited by: Zemp, M., Gärtner-Roer, I., Nussbaumer, S. U., Hüsler, F., Machguth, H., Mölg, N., Paul, F., and Hoelzle, M., ICSU(WDS)/IUGG(IACS)/UNEP/UNESCO/WMO, World Glacier Monitoring Service, Zurich, Switzerland, publication based on database version: doi:10.5904/wgms-fog-2015-11, 2015 . 
Willis, M. J., Melkonian, A. K., Pritchard, M. E., and Rivera, A.: Ice loss from the Southern Patagonian Ice Field, South America, between 2000 and 2012, Geophys. Res. Lett., 39, L17501, doi:10.1029/2012GL053136, 2012a.

Willis, M. J., Melkonian, A. K., Pritchard, M. E., and Ramage, J. M.: Ice loss rates at the Northern Patagonian Icefield derived using a decade of satellite remote sensing, Remote Sens. Environ., 117, 184-198, doi:10.1016/j.rse.2011.09.017, 2012b.

Worni, R., Stoffel, M., Huggel, C., Volz, C., Casteller, A., and Luckman, B.: Analysis and dynamic modeling of a moraine failure and glacier lake outburst flood at Ventisquero Negro, Patagonian Andes (Argentina), J. Hydrol., 444-445, 134-145, doi:10.1016/j.jhydrol.2012.04.013, 2012.

Zemp, M., Jansson, P., Holmlund, P., Gärtner-Roer, I., Koblet, T., Thee, P., and Haeberli, W.: Reanalysis of multi-temporal aerial images of Storglaciären, Sweden (1959-99) - Part 2: Comparison of glaciological and volumetric mass balances, The Cryosphere, 4, 345-357, doi:10.5194/tc-4-345-2010, 2010.
Zemp, M., Thibert, E., Huss, M., Stumm, D., Rolstad Denby, C., Nuth, C., Nussbaumer, S. U., Moholdt, G., Mercer, A., Mayer, C., Joerg, P. C., Jansson, P., Hynek, B., Fischer, A., Escher-Vetter, H., Elvehøy, H., and Andreassen, L. M.: Reanalysing glacier mass balance measurement series, The Cryosphere, 7, 12271245, doi:10.5194/tc-7-1227-2013, 2013.

Zemp, M., Frey, H., Gärtner-Roer, I., Nussbaumer, S. U., Hoelzle, M., Paul, F., Haeberli, W., Denzinger, F., Ahlstrøm, A. P., Anderson, B., Bajracharya, S., Baroni, C., Braun, L. N., Cáceres, B. E., Casassa, G., Cobos, G., Dávila, L. R., Delgado Granados, H., Demuth, M. N., Espizua, L., Fischer, A., Fujita, K., Gadek, B., Ghazanfar, A., Hagen, J. O., Holmlund, P., Karimi, N., Li, Z., Pelto, M., Pitte, P., Popovnin, V. V., Portocarrero, C. A., Prinz, R., Sangewar, C. V., Severskiy, I., Sigurðsson, O., Soruco, A., Usubaliev, R. and Vincent, C.: Historically unprecedented global glacier decline in the early 21 st century, J. Glaciol., 61, 745-762, doi:10.3189/2015JoG15J017, 2015. 